\title{
Kvalitet og prioritering i helsetjenesten
}

\author{
Et viktig politisk mål er at alle norske borgere skal tilbys likeverdige helsetjenester av høy kvalitet, noe det har \\ vært bred politisk enighet om. Et verktøy for å oppnå dette er riktig prioritering. I forlengelsen av dette ble \\ Nasjonalt råd for kvalitet og prioritering i helsetjenesten opprettet i 2007.
}

\author{
Ånen Ringard \\ rin@kunnskapssenteret.no \\ Berit Mørland \\ Bjørn-Inge Larsen \\ Nasjonalt råd for kvalitet og prioritering \\ i helsetjenesten \\ Oslo
}

Den ambisiøse målsettingen om likeverdige helsetjenester for alle har vært tilnærmet uforandret siden oppbyggingen av et offentlig helsevesen kom i gang etter den annen verdenskrig (1).

Helseutgiftene var i 2009 på ca. 228 milliarder kroner (2), noe som gjør Norge til et av landene i verden som bruker mest penger per innbygger på helse (3). Denne erkjennelsen har ført til politisk aksept for - og et rammeverk for - å prioritere innenfor helsetjenestens område. Man ser også en bredere aksept for å prioritere for å oppnå en fordeling av ressursene til der de trengs mest. Sentralt i denne prosessen står de to offentlige utredningene Lønning I (4) og Lønning II (5), hvor bl.a. prinsippene for prioriteringsarbeidet ble utformet. Prinsippene er også blitt nedfelt i pasientrettighetsloven (6). Også internasjonalt er prioritering blitt ansett som et av de viktigste verktøyene man har for å sikre den politiske målsettingen om likeverdige helsetjenester (7).

Kvalitet og prioritering ble viet stor oppmerksomhet i Nasjonal helseplan for perioden 2007-10 (8). I planen understreket den daværende regjeringen bl.a. at de to temaene i større grad burde ses isammenheng på nasjonalt nivå. En viktig forutsetning for å få dette til var å etablere tydelige ansvarsposisjoner og arenaer for samhandling i helsetjenesten. Samtidig ble det erkjent at det fantes få organisatoriske treffpunkter for de ansvarsbærende aktørene $i$ helsetjenesten. I tillegg hadde flere høringsinstanser tatt opp behovet for et nytt, overordnet organ med oppgaver innen kvalitet og prioriteringer.

På denne bakgrunn besluttet Helse- og omsorgsdepartementet å etablere et nasjo- nalt råd for kvalitet og prioritering. Rådet hadde sitt første møte $\mathrm{i}$ april 2007. I denne kronikken vil vi beskrive rådet og dets virke i den første mandatperioden (2007-10) og noen av rådets viktigste utfordringer.

\section{Nasjonalt råd}

Nasjonalt råd for kvalitet og prioritering kan ses på som en videreføring av det tidligere Prioriteringsrådet som eksisterte $\mathrm{i}$ årene 2000-06. I forbindelse med etableringen av Nasjonalt råd utarbeidet Helseog omsorgsdepartementet et mandat (9). I mandatet heter det bl.a. at rådet skal være sammensatt av ledere fra virksomheter med

\section{«Hensikten med etable-} ringen var bl.a. å tydeliggjøre ulike aktørers rolle og ansvar på området, bedre samhandlingen mellom nivåene og skape mer åpenhet»

ansvar for å tilby helsetjenester, forvaltningen, pasient- og brukerorganisasjoner og universiteter og høgskoler.

Hensikten med etableringen var bl.a. å tydeliggjøre ulike aktørers rolle og ansvar på området, bedre samhandlingen mellom nivåene og skape mer åpenhet. Rådet skulle ha en rådgivende funksjon i spørsmål knyttet til kvalitet og prioritering i helsetjenesten, og det ble pekt på at rådet ikke kunne gi pålegg om hvordan den enkelte virksomhet skulle følge opp eventuelle tilrådinger.

Samtidig er det fra politisk hold ved gjentatte anledninger blitt understreket en forventning om at helsetjenestens aktører følger opp vedtakene. Vi har tidligere beskrevet rådets arbeidsform $(10,11)$.
I tilknytning til rådet ble det etablert et eget sekretariat i Nasjonalt kunnskapssenter for helsetjenesten.

\section{Saker behandlet}

Rådet besto i perioden 2007-10 av 25 medlemmer. Rådets leder har vært, og er, helsedirektør Bjørn-Inge Larsen. Medlemmene er oppnevnt av Helse- og omsorgsdepartementet, og det er ikke oppnevnt varamedlemmer.

Det er blitt avholdt 4-5 heldagsmøter hvert år (totalt $18 \mathrm{i}$ mandatperioden). Hvert år er det blitt behandlet 9-13 større drøftingssaker som har ført til konkrete tiltak, enten i helseforvaltningen eller helsetjenesten (11). I tillegg har rådet behandlet en rekke orienteringssaker, med hovedformål å gi rådets medlemmer økt innsikt $i$ helsetjenestens mange utfordringer.

I figur 1 viser vi hvordan drøftingssakene fordeler seg på de to hovedtemaene og saker som ikke naturlig faller inn under de to temaene, for eksempel saker som omhandler rådets egen arbeidsform.

De første årene var det en stor overvekt av prioriteringssaker, som tilgang til kostbare legemidler, behandling av kolorektal kreft og nyfødtscreening. I 2010 utgjorde kvalitetssaker om lag en tredel av sakene, som hvordan man kunne få til en god og likeverdig behandling for pasienter med sjeldne sykdommer. Hvorvidt tendensen til en jevnere fordeling av temaene vil fortsette, gjenstår å se.

I den første mandatperioden var det kun rådets medlemmer og sekretariatet som hadde anledning til å fremme saker for behandling. Et gjennomgående trekk i de første årene var at det i all hovedsak var representantene fra den sentrale helseforvaltningen og de regionale helseforetakene, i tillegg til sekretariatet, som fremmet forslag til saker. Dette ga en overvekt av, og dermed oppmerksomhet rundt, problemstillinger fra spesialisthelsetjenesten. Mot slutten av perioden jevnet dette seg mer ut med flere forslag både fra tilbyderne av tjenestene og brukerrepresentantene.

Ser vi på hvilke saker som har fått mest oppmerksomhet i den første mandatperioden, 


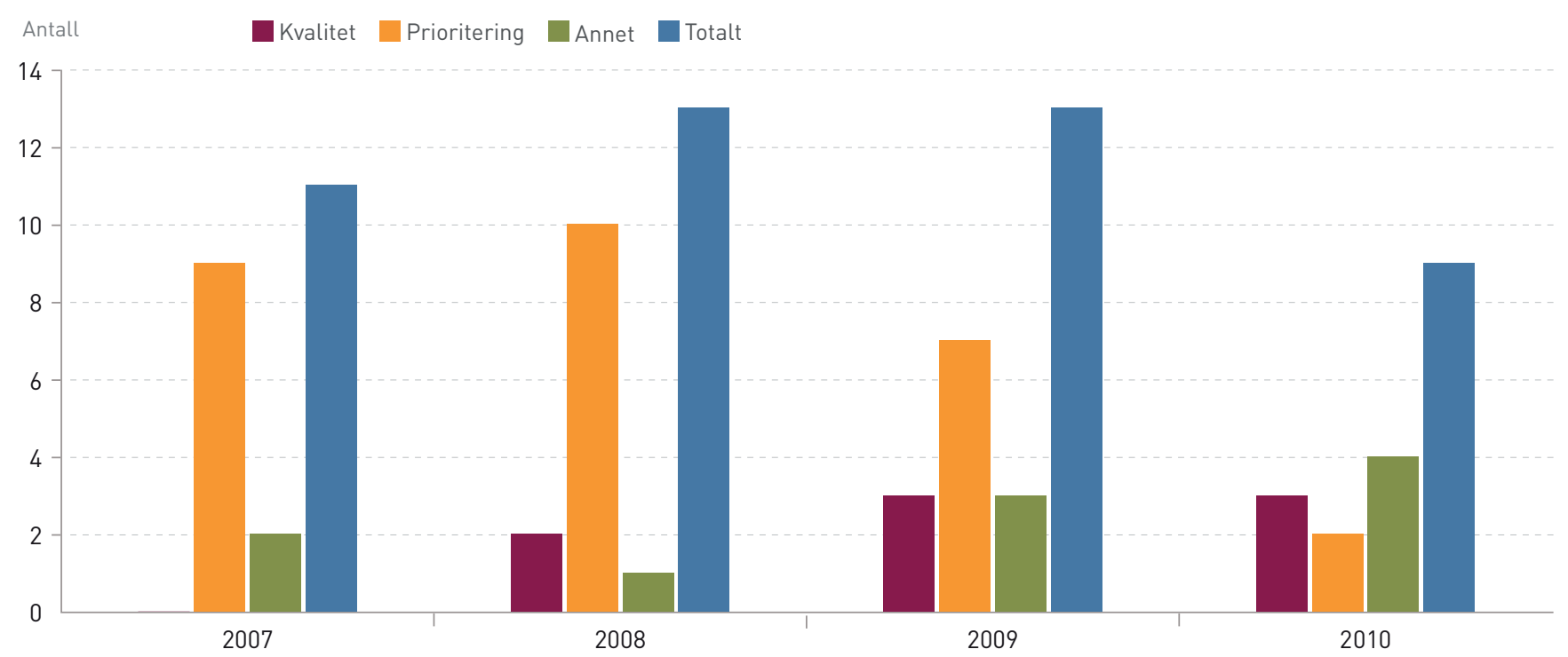

Figur 1 Antall drøftingssaker i Nasjonalt råd for kvalitet og prioritering i helsetjenesten, fordelt på tema. De første årene (2007-09) var det en stor overvekt av prioriteringssaker, mens i 2010 var det en jevnere fordeling mellom de ulike saksområdene

er det særlig saken om innføring av vaksine mot humant papillomvirus (HPV) i det nasjonale barnevaksinasjonsprogrammet som kan fremheves. Rådet behandlet saken i 2007-08. Saken er i seg selv interessant, samtidig som den illustrerer hvordan rådet arbeider. I denne saken ble det, etter at rådet hadde fått utarbeidet en rekke dokumenter og gjennomført omfattende diskusjoner, gitt en anbefaling om å innføre vaksinen. Helse- og omsorgsdepartementet fulgte opp anbefalingen gjennom å bevilge penger til vaksinen på statsbudsjettet for 2009. Vaksineringen kom i gang fra skoleåret 2009-10. Saken er blitt oppfattet som en god illustrasjon på at «vanskelige» saker kunne føre til gode og legitime beslutninger når diskusjonene baseres på kunnskap av høy kvalitet om alle sider av problemstillingen, inkludert etiske aspekter og organisatoriske konsekvenser for helsevesenet (11).

\section{Diskusjon}

Våren 2010 ble det gjennomført en evaluering av rådet. Målet var å oppsummere erfaringer med rådets virksomhet så langt og vurdere erfaringene opp mot intensjonene med etableringen av rådet (12). I evalueringen pekte man på flere utfordringer for rådets arbeid. En av disse var skjevheten i saksomfang mellom helsetjenestens sektorer. Rådet har hatt relativt få saker fra kommune- og primærhelsetjenesten. Det kan være flere årsaker til dette. En forklaring kan være den svakere styringslinjen mellom den nasjonale helseforvaltningen og kommunehelsetjenestens ulike utøvere. At den organisatoriske tilknytningen oppleves som svakere enn den som finnes innenfor spesialisthelsetjenesten, kan gjøre det vanskeligere å fremme saker fra kommunal sektor. I forlengelsen av dette fremkommer det også at for deler av tjenestene, som allmennlegetjenesten, i liten grad finnes et nasjonalt felles faglig nivå. Disse utfordringene er ikke uoverkommelige, men viktig å være klar over i den kommende mandatperioden.

Nasjonalt råd har i løpet av den første perioden fattet flere vedtak som innebærer at man ikke har innført kostbar behandling - til tross for at enkelte pasienter ville kunne ha hatt nytte av den. Slike vedtak innebærer en særlig utfordring for rådets medlemmer fra pasient- og brukerorganisasjonene. Til tross for dette har de på lik linje med rådets øvrige medlemmer deltatt i diskusjonene om hvordan best fordele helsetjenestens ressurser, selv i situasjoner hvor en pasientgruppe de til daglig har ansvar for, ikke har fătt full tilgang til en gitt behandling. De har i mange saker kunnet gi rådets øvrige medlemmer økt innsikt i pasientenes perspektiver. På denne måten har brukerrepresentantene vært med på å sikre enstemmige og tydelige vedtak i kompliserte saker.

I forlengelsen av dette må også helsepolitikerne, som mottakere av rådets anbefalinger, fremheves. Så langt har de uten unntak valgt å lytte til og støtte opp om implementeringen av anbefalingene. Denne støtten har vært, og vil også fremover være helt avgjørende for at rådets arbeid skal ha den nødvendige legitimitet i helse- og omsorgssektoren.

Det fremgår videre av figur 1 at spørsmål knyttet til tjenestens kvalitet ikke har hatt en tilstrekkelig stor plass blant de sakene som rådet har drøftet. Det kan skyldes at dette er problemstillinger som i større grad enn prioriteringsspørsmålet kan håndteres innenfor tjenestene selv. Nasjonale systemer for kvalitetsstyring innen alle deler av helsetjenesten bør imidlertid være gjenstand for rådets oppmerksomhet. Så langt har informasjon om kvalitetsindikatorer, helseregistre og sammenhengen mellom behandlingsvolum og kvalitet blitt lagt frem til diskusjon i rådet. Debatten om disse og liknende overordnede problemstillinger bør videreføres i kommende periode.

En utfordring har også vært å følge opp alle forventningene som ble presentert i Nasjonal helseplan (8), i stor grad fordi rådet til enhver tid har vært avhengig av hvilke saker som har vært spilt inn, og hvor egnede disse har vært for rådets arbeidsform (10).

I løpet av perioden ble det i tillegg startet opp flere parallelle utredninger, uten at rådet var direkte involvert, på områder hvor rådet etter sitt mandat var tiltenkt en rolle, f.eks. innenfor temaet landsfunksjoner og høyspesialiserte tjenester. Rådet er i etterkant av disse prosessene blitt tildelt en tydeligere rolle i forbindelse med den videre oppfølgingen av sakene.

\section{Nytt mandat}

Helse- og omsorgsdepartementet besluttet ved årsskiftet 2010-11 å videreføre Nasjonalt råd, med noen få endringer i mandatet. En viktig endring er at det ikke lenger bare er medlemmene og sekretariatet som kan fremme saker for behandling. Denne muligheten er nå i prinsippet åpen for alle.

Om saken i neste omgang skal komme opp til diskusjon, er det fortsatt opp til rådets medlemmer å bestemme.

Rådet har dessuten fått utvidet sitt mandat (2011-15) til å omfatte omsorgssektoren, noe som også reflekteres i det nye navnet - Nasjonalt råd for kvalitet og prioritering i helse- og omsorgssektoren. I spørsmål om innføring av ny teknologi trenger ikke rådet lenger å avgrense diskusjonene til det som gjelder sykehusene, men kan ta opp slike problemstillinger innenfor hele helse- og omsorgstjenestens ansvarsområde. 


\section{Ånen Ringard (f. 1970)}

er siden 2007 seniorrådgiver i sekretariatet for Nasjonalt råd for kvalitet og prioritering i helsetjenesten. I perioder har han fungert som sekretariatets leder. Han er utdannet statsviter (cand. polit.) fra Universitetet i Oslo. Tidligere har han arbeidet som helsetjenesteforsker ved Institutt for helseledelse og helse$\varnothing$ øonomi, Universitetet i Oslo, og som vitenskapelig assistent ved Institutt for allmennog samfunnsmedisin samme sted.

Ingen oppgitte interessekonflikter.

\section{Berit Mørland (f. 1942)}

er tidligere leder av sekretariatet for Nasjonalt råd for kvalitet og prioritering i helsetjenesten (2007-2010), og assisterende direktør i Kunnskapssenteret. Hun er utdannet tannlege og har arbeidet innen medisin ved universitetene i Tromsø og Oslo. Hun har en doktorgrad i immunologi. Tidligere var hun direktør i Senter for medisinsk metodevurdering. Før dette hadde hun ulike ledende stillinger i Norges forskningsråd, Forskerforbundet og Nordisk institutt for studier av innovasjon, forskning og utdanning.
Oppgitte interessekonflikter: Sekretariatet ved Nasjonalt kunnskapssenter for helsetjenesten er statlig finansiert for å drive Nasjonalt råd for kvalitet og prioritering i helsetjenesten.

\section{Bjørn-Inge Larsen (f. 1961)}

er helsedirektør. Han er utdannet lege og har mastergrader i business administration og public health. Han har ledet Helsedirektoratet siden 2002 og har vært leder av Nasjonalt råd for kvalitet og prioritering i helsetjenesten siden starten i 2007.

Ingen oppgitte interessekonflikter.

\section{Litteratur}

1. Schiøtz A. Helsetjenester og rettferdighet. Tre blikk på norsk helsehistorie. Michael 2008; 5: 180-96. www.dnms.no/index.php?seks_ $i d=71314 \& a=1(12.12 .2011)$.

2. Statistisk sentralbyrå. Helseregnskapet 1997-2009: Helseutgiftene fortsetter å øke. www.ssb.no/vis/emner/09/01/helsesat/art2011-05-19-01.html (12.12.2011).

3. OECD. Health data 2011. www.oecd.org/health/ healthdata (12.12.2011).

4. Norges offentlige utredninger. Retningslinjer for prioritering innen norsk helsetjeneste. NOU 1987 23
5. Norges offentlige utredninger. Prioritering på ny. Gjennomgang av retningslinjer for prioritering innen norsk helsetjeneste. NOU 1997: 18.

6. Lov 1999-07-02 nr. 63. Lov om pasientrettigheter (pasientrettighetsloven). www.lovdata.no/all hl-19990702-063.html (12.12.2011).

7. Klein R, Day P, Redmayne S. Managing scarcity priority setting and rationing in the national health service. Buckingham: Open University Press, 1996.

8. Helse- og omsorgsdepartementet. Nasjonal helse- og omsorgsplan (2007-2010). Særtrykk av st.prp. nr. 1 (2006-2007), kapittel 6.

9. Nasjonalt råd for kvalitet og prioritering i helsetjenesten. Mandat. www.kvalitetog prioritering.no (12.12.2011)

10. Ringard $\AA$, Mørland B, Røttingen JA. Åpne proses ser for prioritering. Tidsskr Nor Lægeforen 2010; 130: 2264-6.

11. Mørland B, Ringard A, Røttingen JA. Supporting though decisions in Norway: a healthcare system approach. Int J Technol Assess Health Care 2010 26: $398-404$

12. Nasjonalt råd for kvalitet og prioritering i helsetjenesten. Evalueringsrapport for perioden 2007-2010. www. kvalitetogprioritering.no (12.12.2011)

Mottatt 10.10. 2011, første revisjon innsendt 22.11 2011, godkjent 24.11. 2011. Medisinsk redaktør Trine B. Haugen. 